\title{
ETHICAL LEADERSHIP ASSESSMENT FOR THE ISLAMIC SECONDARY SCHOOL PRINCIPALS
}

\section{Ristapawa Indra}

Sekolah Tinggi Keguruan dan Ilmu Pendidikan (STKIP) Pesisir Selatan

J1. Pelangai, Ranah Pesisir, Kabupaten Pesisir Selatan, Sumatera Barat, Indonesia, 25153

Email:pawa_indra@yahoo.com

\section{Martin Kustati *}

Universitas Islam Negeri (UIN) Imam Bonjol

Jl. Prof. Mahmud Yunus Lubuk Lintah, Anduring, Kuranji, Kota Padang, Indonesia, 25153

*Email corresponding author: martinkustati@uinib.ac.id

Received: 02, 2018. Accepted: 07, 2019. Published: 07, 2019.

\begin{abstract}
This study aims to determine the assessment of ethical leadership in Islamic High School principal; determine the relationship among ethical leadership constructs; and investigates the influence of ethical leadership in terms of value, serve, act justly, and do right to build the community for a common goal. Eight Islamic secondary schools and 80 teachers were selected as respondents for the study. Quantitative data obtained through a questionnaire which is modified from ethical leadership Perceived Leader Instrument Integrity Scale (LIS). The questionnaire was analyzed using mean and standard deviation, Pearson correlation, and path analysis with multiple regressions. The findings show that the assessment of ethical leadership matched with empirical data. It also found that leadership principals in the service of others was developed at the level of an ethical community, and in terms of respect for others is at unethical level. Then, the finding showed that each construct correlated at a moderate level. It also found that the constructs of ethical leadership (serve and act) provided direct influence on the establishment of a community development effort. The study recommended the elements of ethical leadership of respect for others.
\end{abstract}

Keywords: Islamic Concepts of Ethical Leadership, Appreciation, Service, Justice, Honesty, Community Development

\section{ABSTRAK}

Penelitian ini bertujuan untuk menentukan penilaian terbadap etika kepemimpinan dari kepala sekolah, bubungan antara kontsruk etika kepemimpinan, pengaruh etika kepemimpinan dalam bal nilai, pelayanan, kecepatan dalam bertindak dan melakukan hal yang baik dan benar untuk membangun komunitas dalam rangka mencapai tujuan bersama. Delapan sekolah menengah Islam dan 80 guru dipilih untuk menjadi responden dalam penelitian ini, data-data kuantitatif diperoleh dari kuesioner yang dimodifikasi dari instrument skala integritas untuk etika kepemimpinan dalam persepsi orang lain yang dibuat. Hasil kuesioner dianalisis melalui tabapan mean dan standar deviation, pearson correlation dan path analysis with multiple regression. Hasil penelitian menunjukan babwa penilaian etika kepemimpinan cocok dengan data di lapangan. Temuan lain menunjukan bahwa prinsip kepemimpinan dalam bal melayani orang lain mencapai tingkat etika komunitas. Adapun dalam hal penghormatan kepada orang lain, hasil kuesioner menunjukan tingkat yang tidak etis. Temuan penelitian ini juga menunjukan babwa konstruk etika kepemimpinan yang terdiri dari melayani dan bertindak menunjukan pengarubnya yang langsung terbadap upaya pengembangan komunitas. Penelitian ini merekomendasikan agar ada peningkatan untuk komponen etika kepemimpinan dalam hal menhormati terbadap orang lain.

Kata Kunci: Konsep Islam tentang Etika Kepemimpinan, Nilai, Pelayanan, Kecepatan dalam Bertindak, Pengembangan Komunitas 


\section{INTRODUCTION}

There are numerous researchers (Avolio, Gardner, Walumbwa, Luthans, \& May, 2004; Erdogan, Kraimer, \& Liden, 2004; W. L. Gardner, Avolio, Luthans, May, \& Walumbwa, 2005; Grojean, Resick, Dickson, \& Smith, 2004; Joseph \& Winston, 2005; Pieterse, Van Knippenberg, Schippers, \& Stam, 2010; Russell, 2001) studied about the important roles of the leaders and leadership in organization. In the United States, many suggestions have been raised through reports i.e. "A Nation At Risk, 1983", "Action For Excellence, 1983", "Better Education For Michigan Citizen: A Blue Print For Action, 1984", and "Leader For America's Schools, 1987", that asserted the importance of leadership behavior to an organization. The researchers spoke of effective leadership and the close connection between strong leadership and the success of organization. Likewise in the perspective of school leadership, researches by Bryk \& Schneider (2003); Coburn \& Talbert (2006); DiPaola \& Walther-Thomas (2003); Elmore (2002); Hale \& Moorman (2003); Hallinger (2005); Hoy, Smith, \& Sweetland (2002); Salazar (2007); Sweetland \& Hoy (2000); Youngs \& King (2002) asserted that principals have major roles to determine and to develop the quality of school organization.

In a more specific context, there have also been many studies conducted by educational experts and observers on the close ties between the various principals' leadership assessment and effective schools. Blase \& Kirby (2008); Bush, Kiggundu, \& Moorosi (2011); DuFour \& Eaker (2009); Edmonds (1979); Hallinger (2005); Indra \& Kustati (2016); Saat \& Zain (2016); Southworth (2002) affirmed that a school that shows significant progress in achieving its intended purpose is usually led by a good and effective school principals. The same is also stated by Leithwood, Aitken, \& Jantzi (2006) that principal leadership is widely viewed as one of the decisive factors for school performance success.

Research on the teaching leadership model also explains the close connection between instructional leadership and school performance. A study conducted by Indra \& Kustati (2016) on effective principal leadership explained that there have been shifts in the headmaster's function from a managerial to a teaching leadership. The principal has focused more on teaching leadership than on school-related administration. Effective schools can only be realized by principals who understand the role in the school's teaching program. They do not only understand but aspire to carry out their responsibilities for the academic achievement of their students comprehensively. Davis, Darling-Hammond, LaPointe, \& Meyerson (2005); Halverson, Grigg, Prichett, \& Thomas (2007); Lunenburg \& Ornstein (2011); Muijs, Harris, Chapman, Stoll, \& Russ (2004); Seashore Louis, Dretzke, \& Wahlstrom (2010); Wagner (2014) said that studies of principal leadership in teaching conducted in most countries find that school principals who have proficiency in teaching leadership has the ability to make change of the teaching and learning process.

There is also research on school leadership in terms of transformational leadership concepts initiated by Kuhnert (1994), Bass (1995) and continued by Bass \& Avolio (1997) and Transactional leadership concepts by Bush \& Glover (2003); Gregory Stone, Russell, \& Patterson (2004); Judge \& Piccolo (2004); McCleskey (2014); Nguni, Sleegers, \& Denessen (2006) and Hersey, Blanchard, \& Johnson (2007). Research on the quality of one's leadership and its relation to the quality of a set of knowledge that he has in the aspects of teaching and its relation to emotional intelligence has also been widely practiced. The relationship between leaders' emotions and their effects on teams and outcomes has been introduced by Goleman (2003); Goleman, Boyatzis, \& McKee (2013). (Goleman D. , 2006; Goleman, Boyatzis, \& McKee, 2013; Prati, Douglas, Ferris, Ammeter, \& Buckley, 2003) explain that many smart people fail to be successful because of their lack of sensitivity and interpersonal skills, and emotional intelligence. Thus, it is required to have a set of leadership competencies oriented to emotional intelligence in order to exemplify the efficient school climate. Competence by 
Goleman et al. (2013) divides into four main components: (a) self-awareness, (b) selfmanagement, (c) social awareness, and (d) relationship management.

The late 20th century research on effective leader and leadership has also evolved into the research on ethical leadership. In 1996, an article about ethical leadership was presented by a group of leadership experts compiled by the W.K Kellogg Foundation written in a book entitled Ethics, the Heart of Leadership (Ciulla, 2014). Research on ethical leadership is also put forward by (Northouse, 2015). Leadership is not just a process in which leaders influence others to achieve common goals. But the ethics of a leader is also an important factor that can influence a leader's success in realizing the vision and mission of an organization (Batool, 2013; Boyatzis \& McKee, 2005; H. E. Gardner, 2011; Hackman \& Johnson, 2013; Hargreaves \& Fink, 2012; Hollander, 2012). The ethical dimensions of a leader also have an impact on the life they lead. This sense implies that a leader has an ethical responsibility to treat followers with respect, as a unique identity human being. The same point of view is also put forward by who stated that an ethical leader who gives rewards to the others demands that he would be sensitive of the prominences, needs, and take the responsibilities of the followers. Ethics is important for every leader, according to Northouse (2018) a leader helps to build and to strengthen the organizational values (Avolio et al., 2004; B. M. Bass \& Avolio, 1997; M. E. Brown \& Treviño, 2006; Grojean et al., 2004; Hsiung, 2012; Mayer, Salovey, \& Caruso, 2000; Zhu, Avolio, Riggio, \& Sosik, 2011).

Long before the scientific study of ethical leadership in the late 20th century, the essences of leaders and ethical leadership in the 7th century has been conversed by Islam. The concept of leadership in Islam which is often referred as the Caliph is pretty much explained in the Quran and the Hadith that explains about the proper leader, their duties and responsibilities as well as the essential traits or behaviors of the leaders. In the Islamic perspective, the core mission of a Caliph is to bring balance to the earth. The obligation of a Caliph contains an ethical dimension in which a leader in Islamic point of view must be trustworthy, honest, exemplary, and able to bring harmony for the society as well as for the nature. The Holy Quran and Hadith assert that ethical leaders are the leaders who are trustworthy, honest, fair, and full of justice. Therefore, ideally Islam requires for a Caliph to meet several criteria i.e. adil (qisth, equalizing, leveling), amanah (accountability), dakwah (sociality), and ummah (collectivity) that have become the birth of the concept of "civil leadership" or a concept of leadership that is based on and strengthened with the concept of ummah (Ishak, 2011; Zuhdi, 2014).

Ishak (2011) and Zuhdi, (2014) state that some principles of ethical leadership in Islamic concepts are also in harmony with the concept of ethical leadership by Shapiro \& Stefkovich (2016) who has proposed a unique ethical leadership approach. This approach stressed on how a leader helps followers to confront the conflict and overcome the conflict by implementing the change. Their perspective is related to the value of the worker, the value of the organization and the society of the organization itself. According to Shapiro \& Stefkovich (2016), an ethical leader is the one who is able to help followers in overcoming values that contradictory with the organization.

In more specific context, the Islamic concepts of ethical leadership as proposed by Ishak (2011); Zuhdi, (2014), and Northouse (2015) have similar principals. The further explanation is, Northouse (2018) put forward five principles of ethical leadership that can be implemented within the organization. These five principles can provide the basis for the development of a strong ethical leadership i.e.: 1) respect others; 2) serving others; 3) show justice; 4) displaying honesty; and 5) building community. Ethical leaders are leaders who can appreciate others and also enable them to be themselves (Bolman \& Deal, 2017; Mendonca, 2001; Michie \& Gooty, 2005). The ethical leader also has the responsibility to serve others, and with the emphasis on the well-being of the followers (Senge, 2006). Ethical leaders are also related to justice and equality issues (Rawls, 2009). The ethical leader will prioritize equal treatment to all followers. 
Justice will require leaders to put the issue of justice as the core of their decision. The next ethical leader is also an honest leader. Rivli (2002), had clearly explained in the book entitled "The Ethical Imperative", stated that honesty is more tolerable than lying. For an organization leader, honest means that you should not promise anything you cannot fulfill; do not tell lie; do not hide behind a rotating stone wall; do not ignore your responsibilities; and do not avoid accountabilities. An ethical leader is a leader who builds a community. It is translated as a leader who can influence others and/or as a person who can influence other individuals in the organization to achieve the common goals. An ethical leader is taking into account everyone's goals in the organization; is taking care of the others' goals; and is not forcing or ignoring others prominences (Bernard M. Bass, 1997).

The study aims to: (1) determine the assessment of ethical leadership in Islamic High School principal, (2) to determine the relationship between ethical leadership constructs, and (3) to find out the influence of ethical leadership in the aspect of appreciating, serving, acting justly, and acting honestly towards the aspects of the leaders' abilities in embodying community to achieve the common goals. The quality of the principals' leadership to be seen in the study is related to the principals' ethical leadership from the school's citizens' point of view. This leadership will be able to demonstrate a leader's leadership level at a very ethical, ethical, unethical, and highly unethical stage.

\section{METHOD}

This type of this research is associative research which aims to determine the relationship between two or more variables. This research has the highest level in compared with descriptive and comparative research. Within this research, we will generate a theory to explain, predict and guard a symptom. The population of this study refers to 16 Islamic Secondary High Schools in Padang and their 1340 teachers. Based on the sample determination table by (Krejcie \& Morgan, 1970), 8 Islamic secondary schools were involved in this study. The selection of teacher respondents for each school is defined as 7 to 10 teachers from the total teachers in each sample school (Ary, Jacobs, Sorensen, \& Walker, 2013).

To examine the extent to which the contents of the instrument represent the constructs of Appreciation (X1), Serving (X2), Justice (X3), Honesty (X4), and Community Development (X5), construct validity using exploratory factor analysis with criteria KMO and Anti image $\geq$ 0.5 and Component matrix of single dimension. Instrument items that have a load factor $>0.5$ are items that will be retained as valid items. While the reliability of the instruments of Ethical leadership constructs using the formula of Alpha Cronbach. The instrument reliability criterion is a coefficient reliability of alpha of 0.70 or more so that the instrument grain is declared reliable (J. D. Brown, 2002; Cronbach \& Shavelson, 2004).

Meanwhile, to determine the principals' leadership category, whether including the category of ethical leader or highly unethical is done by descriptive analysis with revised minimum score interpretation based on Perceived Leader Integrity Scale (Northouse, 2018) The minimum score of $1.00-1.75$ indicates ethical leaders, minimum scores of $1.76-2.50$ indicate ethical leaders, min scores of $2.51-3.25$ indicate unethical leaders and the minimum score of $3.26-4.00$ is a very unethical leader. Interpretation of minimum scores can be seen in Table 1.

Table 1. Interpretation of Ethical Leadership Minimum Scores into Four Categories.

\begin{tabular}{lll}
\hline No. & Minimum Score & Interpretation \\
\hline 1 & $1.00-1.75$ & Ethical Leadership \\
2 & $1.76-2.50$ & Fairly Ethical Leadership \\
3 & $2.51-3.25$ & Unethical Leadership \\
4 & $3.26-4.00$ & Very unethical Leadership \\
\hline
\end{tabular}


Then, Pearson correlation analysis technique is used to determine correlation between variables and path analysis technique to get the value of direct and indirect influence by using multiple regression analysis with intervening variable. Intervening variable is the intermediate or mediating variable, which serves to mediate the relationship among variables. In this study, the parameters of variables are: Appreciation (X1), Serving (X2), Justice (X3), Honesty (X4), and Community Development (X5) are shown in Figure 1.

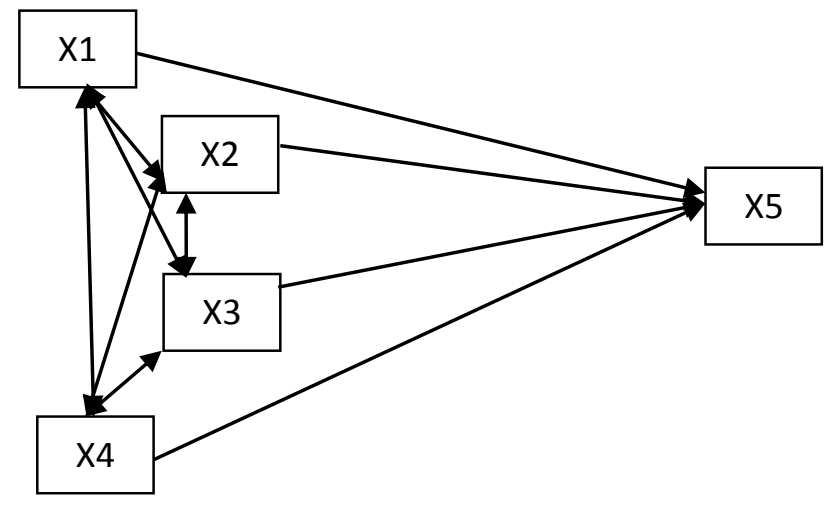

Figure 1. The Parameters of Relationship among Variables.

Figure 1states that the path diagram consists only of a substructure (which is also the complete structure), which contains four exogenous variables $\mathrm{X} 1, \mathrm{X} 2, \mathrm{X} 3, \mathrm{X} 4$ and an endogenous variable, $\mathrm{X} 5$, the structural equation for the path diagram is:

$$
\mathrm{X} 5=\varrho \mathrm{X} 5 \mathrm{X} 1 \mathrm{X} 1+\varrho \mathrm{X} 5 \mathrm{X} 2 \mathrm{X}+\varrho \mathrm{X} 5 \mathrm{X} 3 \mathrm{X} 3+\varrho \mathrm{X} 5 \mathrm{X} 4 \mathrm{X} 4+\varepsilon
$$

\section{RESULTS AND DISCUSSION}

Validity constructs aims to examine the extent to which the content of the instrument item represents a construct considered to be a conceptual framework. The result of validity test of construct through Explanatory Factor Analysis obtained by KMO value $\geq 0.05$ and Anti Image Correlation value for each item of $>0.05$ and reliability test of probability test obtained Corrected Item Total Correlation value exceeds 0.30 and Cronbach Alpha Item Deleted value more than 0.60 which can be seen in the following table below:

Table 2. Summary of Test Results on the Validity and Reliability of Ethical Leadership Constructs.

\begin{tabular}{|c|c|c|c|c|c|}
\hline Variables & $\mathrm{KMO}>0.5$ & $\begin{array}{c}\text { Anti- } \\
\text { Image } \\
\text { Correlation }\end{array}$ & $\begin{array}{c}\text { Matrix } \\
\text { Components }\end{array}$ & $\begin{array}{l}\text { Corrected } \\
\text { Item Total } \\
\text { Correlation }\end{array}$ & $\begin{array}{c}\text { Cronbach's } \\
\text { Alpha Item } \\
\text { Deleted }\end{array}$ \\
\hline Appreciation(X1) & 0.708 & $\begin{array}{l}0.548- \\
0.882\end{array}$ & $>0.5$ & 0.468 & 0.819 \\
\hline Serving (X2) & 0.828 & $\begin{array}{l}0.776- \\
0.863\end{array}$ & $>0.5$ & 0.651 & 0.769 \\
\hline Justice (X3) & 0.618 & $\begin{array}{l}0.453- \\
0.752\end{array}$ & $>0.5$ & 0.455 & 0.817 \\
\hline Honesty (X4) & 0.711 & $\begin{array}{l}0.673- \\
0.775\end{array}$ & $>0.5$ & 0.353 & 0.831 \\
\hline $\begin{array}{l}\text { Community } \\
\text { Development (X5) }\end{array}$ & 0.481 & $\begin{array}{l}0.491- \\
0.772\end{array}$ & $>0.5$ & 0.589 & 0.781 \\
\hline
\end{tabular}


To measure the integrity of ethical leadership of the principals of Islamic High Schools in Padang as a whole, an instrument consisting of 25 items has been grouped into five variables or constructs, i.e. Appreciation (X1), Serving (X2), Justice (X3), Honesty (X4), and Community Development (X5). The minimum score obtained from the instrument that the respondent has answered is interpreted into four categories as shown in Table 1 above. A min score closes to 1.00 represents the principal including the ethical leader; if the min score reaches closer to 4.00 depicting the principal is very unethical.

The results the study show the overall leadership of principals in the category of ethical principals in the Serving aspect with minimum score (1.764), Justice with minimum score (1.387), Honesty with minimum score (1.622), and Community Development with minimum score (1.406). While in the aspect of Appreciation, the headmasters are included in a fairly ethical category.

A more detailed analysis of the 25 instrument points indicates that there are four instruments with the lowest minimum score close to (1.00) describing that the respondent agreed that the principals are the ethical leaders with indicators; never entirely retains any useful information or feedback, with minimum score (1.133). For instrument items, respondents also agreed that the principal included a trustworthy leader in terms of classified information with min scores (1.156). The respondents also agree that the principal is a leader who never altogether lets others be blamed for his mistakes with min scores (1.132). As for the two items of the instrument about the principal who rejected the subordinates' request/proposal and did not want to listen to their opinions or ideas, the respondent agreed that the principals are categorized as fairly ethical leaders.

Table 3. Acquisition of Min Score of Ethical Leadership of Principal.

\begin{tabular}{lccc}
\hline \multicolumn{1}{c}{ Variables } & Mean & Std. Deviation & Category \\
\hline Appreciation(X1) & 1.764 & 0.7714 & Fairly Ethical \\
Serving (X2) & 1.387 & 0.5533 & Ethical \\
Justice (X3) & 1.231 & 0.4389 & Ethical \\
Honesty (X4) & 1.622 & 0.6718 & Ethical \\
Community Development (X5) & 1.406 & 0.6637 & Ethical \\
\hline
\end{tabular}

Pearson correlation is used to see the correlation between components with relationship value $(\mathrm{r})$ interpreted into three stages.

Table 4. Relationship Level between Two Variables.

\begin{tabular}{ccl}
\hline No. & Correlation $(\mathrm{r})$ & Relationship Level \\
\hline $0.70-1.00$ & High \\
$0.30-0.69$ & Fair \\
$0.00-0.29$ & Low \\
\hline
\end{tabular}

Source: (Northouse, 2018).

The results of the analysis among variables as a whole can be seen in Table 5 below:

Table 5. The Results of the Analysis among Variables.

\begin{tabular}{llllll}
\hline & \multicolumn{1}{c}{$\mathrm{X} 1$} & \multicolumn{1}{c}{$\mathrm{X} 2$} & $\mathrm{X} 3$ & $\mathrm{X} 4$ & $\mathrm{X} 5$ \\
\hline $\mathrm{X} 1$ & 1.000 & $0.631^{* *}$ & $0.554^{* *}$ & $0.395^{* *}$ & $0.486^{* *}$ \\
$\mathrm{X} 2$ & $0.631^{* *}$ & 1.000 & $0.530^{* *}$ & $0.583^{* *}$ & $0.706^{* *}$ \\
$\mathrm{X} 3$ & $0.554^{* *}$ & $0.530^{* *}$ & 01.000 & $0.364^{*}$ & $0.605^{* *}$ \\
$\mathrm{X} 4$ & $0.395^{* *}$ & $0.583^{* *}$ & $0.364^{*}$ & 1.000 & $0.490^{* *}$ \\
$\mathrm{X} 5$ & $0.486^{* *}$ & $0.706^{* *}$ & $0.605^{* *}$ & $0.490^{* *}$ & 1.000 \\
\hline
\end{tabular}


Table 5 above shows that: there are correlations at simple stages between X1 and X2, X3, $\mathrm{X} 4$ and X5; simple phase correlations between X2 with X1, X3, X4; high stages between X2 and X5; simple phase correlations between X3 with X1, X2, X4 and X5; and simple phase correlations between $\mathrm{X} 4$ with $\mathrm{X} 1, \mathrm{X} 2, \mathrm{X} 3$ and X5 .

Furthermore, to see the coefficient path, it can be done by multiple regression analysis. The analysis of the study can be seen in the following Table 6 and 7 .

Table 6. Summary Model.

\begin{tabular}{rrrrrrr}
\hline Model & $\mathrm{R}$ & R Square & $\begin{array}{l}\text { Adjusted } \\
\text { R Square }\end{array}$ & $\begin{array}{r}\text { Std. Error of } \\
\text { the Estimate }\end{array}$ & F & Sig. \\
\hline 1 & $.761^{\mathrm{a}}$ & .580 & .538 & .4513 & 13.787 & .000 \\
\hline
\end{tabular}

Table 7. Coefficient path X1 through X4.

\begin{tabular}{llrrrrr}
\hline Model & & \multicolumn{2}{c}{ Un-standardized } & \multicolumn{2}{c}{$\begin{array}{c}\text { Standardized } \\
\text { Coefficients }\end{array}$} & \multicolumn{2}{c}{ Coefficients } & & \\
\cline { 3 - 4 } & & \multicolumn{1}{c}{ B } & \multicolumn{1}{c}{ Std. Error } & \multicolumn{1}{c}{ Beta } & \multicolumn{1}{c}{ S } & \multicolumn{1}{c}{ Sig. } \\
\hline 1 & (Constant) & -.125 & .231 & & -.543 & .590 \\
& X1 & -.050 & .121 & -.058 & -.412 & .682 \\
& X2 & .615 & .184 & .513 & 3.343 & .002 \\
X3 & .501 & .194 & .332 & 2.580 & .014 \\
& X4 & .092 & .125 & .093 & .733 & .468 \\
\hline
\end{tabular}

a. Dependent variable : Community Development

From the result of the coefficient path test, the coefficient path from X2 to X5 and X3 to $\mathrm{X} 5$ both is statistically significant ( $\mathrm{t}$ count above $\mathrm{t}$ table and $p$-value below 0.05), while path coefficient from X1 to X5 and X4 to X5 is not significant ( $\mathrm{t}$ count below $\mathrm{t}$ table and p-value above 0.05$)$. Therefore, the process will be repeated by removing X1 and X4 from the model. The proposition becomes: Serving (X2) and Justice (X3) has a positive influence on Community Development (X5). On the basis of this improved proposition the path diagram becomes as shown in Figure 2 below:

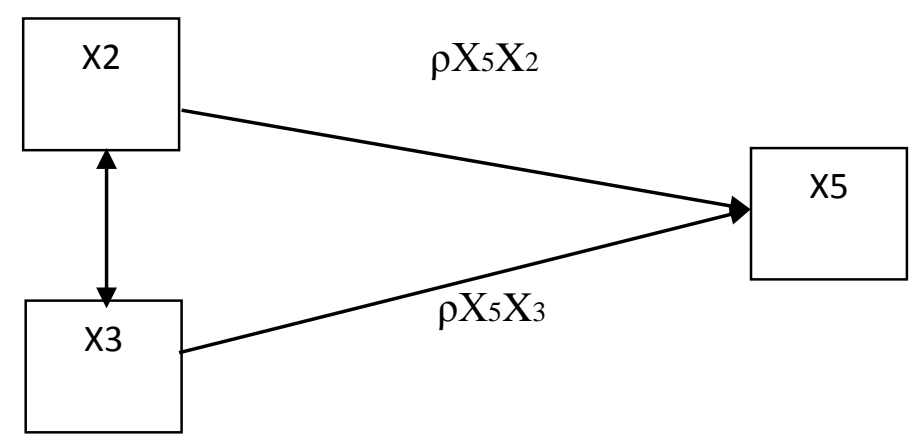

Figure 2. The structural relationship among X2, X3, and X5 with structural equation X5 $=\varrho X 5 X 2 X 2+\varrho X 5 X 3 X 3+\varepsilon$

The path diagram contains only two exogenous variables X2 and X3 and an endogen X5. With the loss of two exogenous modifiers from the path diagram, the magnitude of the path coefficient will change. Thus the calculation should be repeated, as shown in Tables 8 and 9 . 
Table 8. Summary Model.

\begin{tabular}{rrrrrrr}
\hline Model & $\mathrm{R}$ & R Square & $\begin{array}{l}\text { Adjusted } \\
\text { R Square }\end{array}$ & $\begin{array}{r}\text { Std. Error of } \\
\text { the Estimate }\end{array}$ & F & Sig. \\
\hline 1 & $0.756^{\mathrm{a}}$ & 0.572 & 0.552 & 0.4443 & 28.096 & 0.000 \\
\hline
\end{tabular}

Table 9. Coefficient path X2 through X3.

\begin{tabular}{|c|c|c|c|c|c|c|}
\hline \multirow{2}{*}{\multicolumn{2}{|c|}{ Model }} & \multicolumn{2}{|c|}{$\begin{array}{l}\text { Un-standardized } \\
\text { Coefficients }\end{array}$} & \multirow{2}{*}{$\begin{array}{c}\text { Standardized } \\
\text { Coefficients } \\
\text { Beta }\end{array}$} & \multirow[b]{2}{*}{$\mathrm{T}$} & \multirow[b]{2}{*}{ Sig. } \\
\hline & & B & Std. Error & & & \\
\hline \multirow[t]{3}{*}{1} & (Constant) & -0.083 & 0.215 & & -0.387 & 0.700 \\
\hline & $\begin{array}{l}\text { Serving } \\
\text { (X2 }\end{array}$ & 0.642 & 0.143 & 0.536 & 4.502 & 0.000 \\
\hline & $\begin{array}{l}\text { Justice } \\
\text { (X3) }\end{array}$ & 0.486 & 0.180 & 0.321 & 2.700 & 0.010 \\
\hline & & a. De & ent variable & & & \\
\hline
\end{tabular}

The analysis shown table 9 shows that the coefficient of lines X2 and X3 becomes 0.536 and 0.321, and both are significant i.e. Serving (Beta $=0.536, \mathrm{t}=4.502$, sig $=0.00<0.05$ and $\mathrm{R}^{2}=0.378$ ) and Justice (In Beta $=0.321, \mathrm{t}=2.700$, sig $=0.01<0.05$ and $\mathrm{R}^{2}=0.194$ ). In the Summary Model Table 8, it appears that R square becomes 0.572 thus the path coefficient $\varepsilon$ (changeable outside the model) as shown in Figure 3.

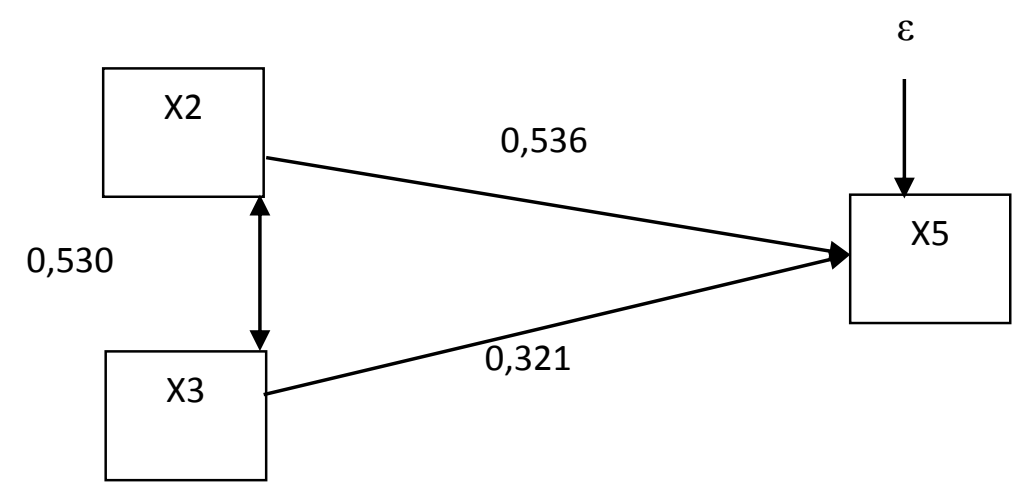

Figure 3. The Structure of Causal Relationship among X2 and X3 to X5.

The combined effect of X 2 and $\mathrm{X} 3$ to $\mathrm{X} 5$ is $0.378+0.194=0.572$ which is nothing but the magnitude of $\mathrm{R} 2 \mathrm{X} 5(\mathrm{X} 2 \mathrm{X} 3)=0.572$ or the combined effect of $\mathrm{X} 2$ and $\mathrm{X} 3$ to $\mathrm{X} 5$ is $57.2 \%$ and the remaining $42.8 \%$ is contributed by other factors.

The research hypothesis is obtained from the results of coefficient test describes that from $\mathrm{X} 2$ to X 5 and X3 to X5 are both significantly influenced ( $\mathrm{t}$ count is higher than $\mathrm{t}$ table and $\mathrm{p}-$ value below 0.05). The results of this analysis prove that hypotheses 2 and 3 are influential between principals' ethical leadership in the aspect of serving (X2) with the ability to build school communities (X5) and there is an influence between the principal's ethical leadership in aspects of being fair (X3) with the ability to build school community (X5). These mean that hypotheses 2 and 3 are acceptable.

While the coefficients path from X1 to X5 and X4 to X 5 do not significantly influenced ( $t$ count below t Table and $\mathrm{p}$-value is higher than 0.05). The results of this analysis prove that hypotheses 1 and 3 are influential i.e. between principals' ethical leadership in aspects of respecting (X1) to the ability to build school communities (X5) and there is an influence between 
principals' ethical leadership in the aspects of being honest (X4) and the ability to build school community (X5) is not accepted.

Based on the above research findings, it shows that the ethical leadership assessment model consisting of five dimensions of Appreciation (X1), Serving (X2), Justice (X3), Honesty (X4), and Community Development (X5) by using 25 series of the valid and reliable questions shows that each indicator can measure each construct of the ethical leadership. The behavioral assessment of a principal based on the scale of behavior from teachers' perspectives by using probing questionnaire is classified as very good in attempt to detect ethical leadership. This assessment model can be applied in taking decision-making and designing a sustainable principals' development program.

The results of the instrument analysis show that the principals of the Islamic High Schools is included as the fairly ethical in Appreciation, Serving, Justice, Honesty, and Community development aspects. This finding is in line with the concept of leadership in the perspective of Islam purposed by Ishak (2011), Zuhdi (2014), and Maimunah (2017) who edify the leaders to respect other, fair, trustworthy, and be able to construct the spiritual integrity. The Holy Quran and Hadith also emphasize that a leader must meet several criteria i.e. adil (qisth, equalizing, leveling), amanab (accountability), dakwah (sociality), and ummab (collectivity) that have become the birth of the concept of "civil leadership" or a concept of leadership that is based on and strengthened with the concept of ummah.

Then, the result of path analysis shows from four independent variables measured turns out that they are directly or indirectly affected through other variable to dependent variable are in Serving and Justice aspects with the effect of together equal to $57.2 \%$. While the next two variables i.e. Appreciation and honesty do not directly affect the effort to develop the community. They are in accordance with research findings by Zhu, He, Trevino, Chao, \& Wang (2015) who argue that ethical leadership has an indirect effect on the performance of followers in the organization.

As Northouse (2018) points out, ethical theory consists of two domains: theories about leader behavior and theories about leader character. Character is included as the invisible leader behavior that forms the basis for behavior seen in the form of action. The results of the analysis show that a leader has the character of respect for others (Appreciation) and realize that others need to be respected does not directly influence the effort in building the community in realizing the shared vision and mission of the team. Appreciation gives meaning when accompanied by action behavior. Likewise, in the aspect of Honesty for a leader is including the character of a leader who underlies the behavior of a leader's actions. Having honest behavior but not being realized in the form of action does not bring meaning to the effort to build the community. As explained by (Avolio \& Locke, 2002; Bass \& Steidlmeier, 1999) that respectful and honest behavior is included in ethical attitudes closely related to the interests of ethical egoism that fall to transactional leadership that puts self-importance instead of team building. Serving and Justice are falling into altruism's behavior, the opposite of ethical egoism. According to Schumann (2001), altruism is an approach that emphasizes that a leader's actions are moral, if his or her main purpose is to sustain the best interests of its members or the community. This study is in accordance with the view of Shekari \& Nikooparvar (2012); Yates (2014) that the behavior of caring for others is the principal shaper of moral leadership, and also in accordance with the results of Janssen (2005) who stated that ethical leadership encourages innovative behavior of services. The study indicated that Islamic High Schools principals in Padang have been aware of the main leaders' tasks in the school. The important task of a leader is to serve the vision and mission of the school organization. Similarly, in terms of ethical leadership related to justice and equality issues, proving the principal in Padang City has acted morally by prioritizing fair treatment of all followers. Rawls (2009) concerned with justice issues is 
important for all people working together, to increase the interests. Caring with justice is a reciprocal ethic of "treating others as you would like to be treated".

\section{CONCLUSION}

Based on the research questions about ethical leadership of the principals of the Islamic High School in Padang can be summarized that the ethical leadership instruments with five variables and 25 indicators have been tested in theory and empirically. The five variables of ethical leadership consisting of Appreciation, Serving, Justice, Honesty, and Community Development have met the validity and reliability aspects and can be used as guidelines for policy makers in establishing and inaugurating a principal.

The five variables of ethical leadership show a simple stage correlation between variables and one variable indicating high-level correlation. Path analysis results found that two of the five ethical leadership variables directly influence community building efforts. The "Serving (X2) variable" directly affects "Community Development (X5)" by 0.287 or $28.7 \%$. Influence through correlation relationship with "Justice (X3)" with "Community Development (X5)" equal to 0.091 or $9.1 \%$. While the direct effect of Justice (X3) with Community Development (X5) of 0.103 or $10.3 \%$. The effect through correlation relationship with X2 is 0.091 or $9.1 \%$. The combined effect of X2 and X3 in combination to X5 is 0.572 or $57.2 \%$. Of the four variables of ethical leadership, associated with ethical selfishness are the variables of respect for others and the variable of doing the truth. While the two variables that serve others and act fairly including the altruism behavior of a leader.

\section{ACKNOWLEDGMENT}

The authors are thankful to STKIP Pesisir Selatan, West Sumatera in collaboration with Faculty of Islamic Education and Teacher Training, UIN Imam Bonjol Padang for providing the necessary facilities for conducting the research and publishing the article. They also thanks to 8 Islamic secondary schools, especially for those respondents that have provided needed data for completing the research.

\section{BIBLIOGRAPHY}

Ary, D., Jacobs, L. C., Sorensen, C., \& Walker, D. (2013). Introduction to research in education: Cengage Learning.

Avolio, B. J., \& Locke, E. E. (2002). Constrating different philosophies of leader motivation: Alturism versus egoism. The Leadership Quarterly, 169-191.

Avolio, B. J., Gardner, W. L., Walumbwa, F. O., Luthans, F., \& May, D. R. (2004). Unlocking the mask: A look at the process by which authentic leaders impact follower attitudes and behaviors. The Leadership Quarterly, 15(6), 801-823.

Bass, B. M. (1995). Theory of transformational leadership redux. The Leadership Quarterly, 6(4), 463-478.

Bass, B. M. (1997). Does the transactional-transformational leadership paradigm transcend organizational and national boundaries?. American Psychologist, 52(2), 130.

Bass, B. M., \& Avolio, B. J. (1997). Full range leadership development: Manual for multifactor leadership questionnaire. California: Mind Gorden. Inc.

Bass, B. M., \& Steidlmeier, P. (1999). Ethics caracter and authentic transformational leadership.

Binghamton NY: School of Management Binghamton University.

Batool, B. F. (2013). Emotional intelligence and effective leadership. Journal of Business Studies Quarterly, 4(3), 84.

Blase, J., \& Kirby, P. C. (2008). Bringing out the best in teachers: What effective principals do. Corwin Press. 
Bolman, L. G., \& Deal, T. E. (2017). Reframing organizations: Artistry, choice, and leadership. John Wiley \& Sons.

Boyatzis, R., \& McKee, A. (2005). Resonant leadership: Renewing yourself and connecting with others through mindfulness, hope and compassioncompassion. Harvard Business Press.

Brown, J. D. (2002). The Cronbach alpha reliability estimate. JALT Testing \& Evaluation SIG Newsletter, 6(1).

Brown, M. E., \& Treviño, L. K. (2006). Ethical leadership: A review and future directions. The Leadership Quarterly, 17(6), 595-616.

Bryk, A. S., \& Schneider, B. (2003). Trust in schools: A core resource for school reform. Educational Leadership, 60(6), 40-45.

Bush, T., \& Glover, D. (2003). School leadership: Concepts and evidence.

Bush, T., Kiggundu, E., \& Moorosi, P. (2011). Preparing new principals in South Africa: the ACE: School leadership programme. South African Journal of Education, 31(1), 31-43.

Ciulla, J. B. (2014). Ethics, the heart of leadership. ABC-CLIO.

Coburn, C. E., \& Talbert, J. E. (2006). Conceptions of evidence use in school districts: Mapping the terrain. American Journal of Education, 112(4), 469-495.

Cronbach, L. J., \& Shavelson, R. J. (2004). My current thoughts on coefficient alpha and successor procedures. Educational and Psychological Measurement, 64(3), 391-418.

Davis, S., Darling-Hammond, L., LaPointe, M., \& Meyerson, D. (2005). Developing successful principals. Stanford Educational Leadership Institute, Ed.). Retrieved February, 20, 2009.

DiPaola, M. F., \& Walther-Thomas, C. (2003). Principals and Special Education: The Critical Role of School Leaders.

DuFour, R., \& Eaker, R. (2009). Professional Learning Communities at Workâ „,: Best Practices for Enhancing Students Achievement. Solution Tree Press.

Edmonds, R. (1979). Effective schools for the urban poor. Educational Leadership, 37(1), 15-24.

Elmore, R. F. (2002). Bridging the gap between standards and achievement: The imperative for professional development in education. Secondary Lenses on Learning Participant Book: Team Leadership for Mathematics in Middle and High Schools, 313-344.

Erdogan, B., Kraimer, M. L., \& Liden, R. C. (2004). Work value congruence and intrinsic career success: the compensatory roles of leader-member exchange and perceived organizational support. Personnel Psychology, 57(2), 305-332.

Gardner, H. E. (2011). Leading minds: An anatomy of leadership. Hachette UK.

Gardner, W. L., Avolio, B. J., Luthans, F., May, D. R., \& Walumbwa, F. (2005). "Can you see the real me?" A self-based model of authentic leader and follower development. The Leadership Quarterly, 16(3), 343-372.

Goleman, D. (2003). What makes a leader. Organizational Influence Processes, 229-241.

Goleman, D. (2006). Kepemimpinan berdasarkan kecerdasan emosi. Bandung: Gramedia Pustaka Utama.

Goleman, D., Boyatzis, R. E., \& McKee, A. (2013). Primal leadership: Unleashing the power of emotional intelligence. Harvard Business Press.

Gregory Stone, A., Russell, R. F., \& Patterson, K. (2004). Transformational versus servant leadership: A difference in leader focus. Leadership \& Organization Development Journal, 25(4), 349-361.

Grojean, M. W., Resick, C. J., Dickson, M. W., \& Smith, D. B. (2004). Leaders, values, and organizational climate: Examining leadership strategies for establishing an organizational climate regarding ethics. Journal of Business Ethics, 55(3), 223-241.

Hackman, M. Z., \& Johnson, C. E. (2013). Leadership: A communication perspective. Waveland Press. Hale, E. L., \& Moorman, H. N. (2003). Preparing school principals: A national perspective on policy and program innovations. Institute for Educational Leadership (NJ1). 
Hallinger, P. (2005). Instructional leadership and the school principal: A passing fancy that refuses to fade away. Leadership and Policy in Schools, 4(3), 221-239.

Halverson, R., Grigg, J., Prichett, R., \& Thomas, C. (2007). The new instructional leadership: Creating data-driven instructional systems in school. Journal of School Leadership, 17(2), 159.

Hargreaves, A., \& Fink, D. (2012). Sustainable leadership (Vol. 6). John Wiley \& Sons.

Hersey, P., Blanchard, K. H., \& Johnson, D. E. (2007). Management of organizational behavior (Vol. 9). Prentice hall Upper Saddle River, NJ.

Hollander, E. (2012). Inclusive leadership: The essential leader-follower relationship. Routledge.

Hoy, W. K., Smith, P. A., \& Sweetland, S. R. (2002). The development of the organizational climate index for high schools: Its measure and relationship to faculty trust. The High School Journal, 86(2), 38-49.

Hsiung, H.-H. (2012). Authentic leadership and employee voice behavior: A multi-level psychological process. Journal of Business Ethics, 107(3), 349-361.

Indra, R., \& Kustati, M. (2016). Effective School Performance Stages at Public Senior High Schools in Indonesia. Al-Ta'lim Journal, 23(2), 100-113.

Ishak, S. (2011). Model Kepemimpinan Etika Berlandas Sirah Nabi Muhammad SAW (Ethical Leadership Model Based on Prophet Muhammad PBUH Biography). Jurnal Hadhari: An International Journal, 3(2), pp.23-44.

Janssen, O. (2005). The joint impact of perceived influence and supervisor supportiveness on employee innovative behaviour. Journal of Occupational and Organizational Psychology, 78(4), 573-579.

Joseph, E. E., \& Winston, B. E. (2005). A correlation of servant leadership, leader trust, and organizational trust. Leadership \& Organization Development Journal, 26(1), 6-22.

Judge, T. A., \& Piccolo, R. F. (2004). Transformational and transactional leadership: a metaanalytic test of their relative validity. Journal of Applied Psychology, 89(5), 755.

Krejcie, R. V, \& Morgan, D. W. (1970). Determining sample size for research activities. Educational and Pshychological Measurement 30, 607-610.

Kuhnert, K. W. (1994). Transforming leadership: Developing people through delegation.

Leithwood, K., Aitken, R., \& Jantzi, D. (2006). Making schools smarter: Leading with evidence. Corwin Press.

Lunenburg, F., \& Ornstein, A. (2011). Educational administration: Concepts and practices. Nelson Education.

Maimunah, M., 2017. Kepemimpinan Dalam Perspektif Islam dan Dasar Konseptualnya. AlAfkar: Jurnal Keislaman \& Peradaban, 5(1). Retrieved from http://ejournal. fiaiunisi.ac.id/index.php/al-afkar/article/view/133

Mayer, J. D., Salovey, P., \& Caruso, D. (2000). Models of emotional intelligence. RJ Sternberg (Ed.).

McCleskey, J. A. (2014). Situational, transformational, and transactional leadership and leadership development. Journal of Business Studies Quarterly, 5(4), 117. Retrieved from https://pdfs.semanticscholar.org/0333/9f1dd37ee4d9182b7fc7ddb33f19d9a92177.pdf

Mendonca, M. (2001). Preparing for ethical leadership in organizations. Canadian Journal of Administrative Sciences/Revue Canadienne Des Sciences de l'Administration, 18(4), 266-276.

Michie, S., \& Gooty, J. (2005). Values, emotions, and authenticity: Will the real leader please stand up? The Leadership Quarterly, 16(3), 441-457.

Muijs, D., Harris, A., Chapman, C., Stoll, L., \& Russ, J. (2004). Improving schools in socioeconomically disadvantaged areas-A review of research evidence. School Effectiveness and School Improvement, 15(2), 149-175. 
Nguni, S., Sleegers, P., \& Denessen, E. (2006). Transformational and transactional leadership effects on teachers' job satisfaction, organizational commitment, and organizational citizenship behavior in primary schools: The Tanzanian case. School Effectiveness and School Improvement, 17(2), 145-177.

Northouse, P. G. (2018). Leadership: Theory and practice. Sage publications.

Northouse, P. G. (2015). Leadership: Teory and pranctice. United States of America: SAGE Publications.

Pieterse, A. N., Van Knippenberg, D., Schippers, M., \& Stam, D. (2010). Transformational and transactional leadership and innovative behavior: The moderating role of psychological empowerment. Journal of Organizational Behavior, 31(4), 609-623.

Prati, L.M.,Douglas, C., Ferris, G.R., Ammeter, A. P., \& Buckley, M. R. (2003). Emotional intelligence, leadership effectiveness, and team outcomes. The International Journal of Organozational Analysis 11, 21-40.

Rawls, J. (2009). A theory of justice: Revised edition. Harvard university press.

Rivlin, L. (2002). The ethical imperative. Handbook of Environmental Psychology, 15-27.

Russell, R. F. (2001). The role of values in servant leadership. Leadership \& Organization Development Journal, 22(2), 76-84.

Saat, L. B., \& Zain, S. (2016). The Effect of Instructional Leadership, Efficacy and Routine Taks Principals of Academic Achievement. Malaysian Journal of Social Sciences and Humanities (MJSSH), 1(3), 42-65.

Salazar, P. S. (2007). The professional development needs of rural high school principals: A seven-state study. The Rural Educator, 28(3).

Schumann, P. L. (2001). A moral principles framework for human resource management ethics. Human Resource Management Review, 11(1-2), 93-111.

Seashore Louis, K., Dretzke, B., \& Wahlstrom, K. (2010). How does leadership affect student achievement? Results from a national US survey. School Effectiveness and School Improvement, 21(3), 315-336.

Senge, P. M. (2006). The fifth discipline: The art and practice of the learning organization. Broadway Business.

Shapiro, J. P., \& Stefkovich, J. A. (2016). Ethical leadership and decision making in education: Applying theoretical perspectives to complex dilemmas. Routledge.

Shekari, H., \& Nikooparvar, M. Z. (2012). Promoting leadership effectiveness in organizations: A case study on the involved factors of servant leadership. International Journal of Business Administration, 3(1), 54.

Southworth, G. (2002). Instructional leadership in schools: Reflections and empirical evidence. School Leadership \& Management, 22(1), 73-91.

Sweetland, S. R., \& Hoy, W. K. (2000). School characteristics and educational outcomes: Toward an organizational model of student achievement in middle schools. Educational Administration Quarterly, 36(5), 703-729.

Wagner, T. (2014). The global achievement gap: Why even our best schools don't teach the new survival skills our children need and what we can do about it. Basic Books.

Yates, L. A. (2014). Exploring the relationship of ethical leadership with job satisfaction, organizational commitment, and organizational citizenship behavior. The Journal of Values-Based Leadership, 7(1), 4.

Youngs, P., \& King, M. B. (2002). Principal leadership for professional development to build school capacity. Educational Administration Quarterly, 38(5), 643-670. https://journals.sagepub.com/doi/10.1177/0013161X02239642 
Zhu, W., Avolio, B. J., Riggio, R. E., \& Sosik, J. J. (2011). The effect of authentic transformational leadership on follower and group ethics. The Leadership Quarterly, 22(5), 801-817. Retrieved from https://pennstate.pure.elsevier.com/en/publications/theeffect-of-authentic-transformational-leadership-on-follower-a

Zhu, W., He, H., Trevino, L. K., Chao, M. M., \& Wang, W. (2015). Ethical leadership and follower voice and performance: The role of follower identifications and entity morality beliefs. The Leadership Quarterly, 26(5), 702-718.

Zuhdi, M.H., (2014). Konsep Kepemimpinan dalam Perspektif Islam. Akademika: Jurnal Pemikiran Islam, 19(1), pp.35-57. 